\title{
Interaction of dietary protein and energy-protein ratio on growth performance of snakehead Channa striata
}

\section{Kinerja pertumbuhan ikan gabus Channa striata yang diberi pakan dengan tingkat protein dan rasio energi-protein}

\author{
Hani Wijianti ${ }^{1}$, Muhammad Agus Suprayudi², Nur Bambang Priyo Utomo², Dedi Jusadi² \\ 'Directorate for Aquaculture Production and Business, Directorate General of Aquaculture, Ministry of Marine \\ Affairs and Fisheries of Republic of Indonesia, Central Jakarta 10110 \\ ${ }^{2}$ Department of Aquaculture, Faculty of Fisheries and Marine Science, IPB University, Dramaga, Bogor, West \\ Java 16680 \\ *Corresponding author : agus.suprayudi1965@gmail.com
}

(Received December 19, 2017; Accepted November 22, 2018)

\begin{abstract}
The study proposed to discover the optimum protein content and energy-protein ratio in practical diet for snakehead, Channa striata. The experiment applied complete randomized design, consisted of six treatments with four replications on each treatment. The treatments were: A $(32.5 \% ; 11.82 \mathrm{kcal} \mathrm{GE} / \mathrm{g}), \mathrm{B}(32.5 \% ; 13.32 \mathrm{kcal}$ GE/g), C (37.17\%; $10.64 \mathrm{kcal} \mathrm{GE} / \mathrm{g})$, D (37.33\%; $12.07 \mathrm{kcal} \mathrm{GE} / \mathrm{g})$, E (43.08\%; $10.02 \mathrm{kcal} \mathrm{GE} / \mathrm{g})$, and F (42.88\%; $10.66 \mathrm{kcal} \mathrm{GE} / \mathrm{g})$. Snakehead with average weight of $6.21 \pm 0.03 \mathrm{~g}$ were reared for 8 weeks. The treatments showed significant results. Increased protein dietary level had increased the growth rate and treatment with high energyprotein ratio at the same protein dietary level provided better growth performance. However, increased energyprotein ratio at $\mathrm{E}$ and $\mathrm{F}$ treatments caused a decline in growth performance. The improvement of energy-protein dietary ratio had positive correlation with the level of lipid and protein content in fish body. Similar finding was found in liver and muscle glycogen. The results also showed that the increament of energy-protein dietary ratio was significantly and positively correlated with cholesterol, triglyceride, HDL, glucose, and albumin, yet it had no significant effect on LDL. It can be concluded that excellent growth performance was achieved by protein dietary level of $37.33 \%$ and energy-protein ratio of $12.07 \mathrm{kcal} \mathrm{GE} / \mathrm{g}$.
\end{abstract}

Keywords: energy-protein ratio, growth, snakehead

\begin{abstract}
ABSTRAK
Penelitian ini bertujuan untuk memperoleh kadar protein dan rasio energi-protein pakan buatan yang optimum bagi performa pertumbuhan ikan gabus. Penelitian ini mengaplikasikan rancangan acak lengkap dengan 6 perlakuan, yaitu: A (32,78\%;11,82 kcal GE/g), B (32,56\%;13,32 kcal GE/g), C (37,17\%:10,64 kcal GE/g), D (37,33\%:12,07 kcal GE/g), E (43,08\%:10,02 kcal GE/g), dan F (42,88\%:10,66 kcal GE/g) dan masing-masing terdiri 4 ulangan. Bobot rata-rata ikan gabus yang digunakan dalam penelitian ini yaitu 6,21 $\pm 0,03 \mathrm{~g}$ dan dipelihara selama 8 minggu. Hasil penelitian menunjukkan bahwa peningkatan kadar protein pakan meningkatkan laju pertumbuhan, dan perlakuan dengan rasio energi-protein tinggi pada level protein pakan yang sama memberikan kinerja pertumbuhan yang lebih baik. Namun demikian, pada perlakuan E dan F, peningkatan rasio energi-protein menyebabkan penurunan kinerja pertumbuhan. Peningkatan rasio energi-protein pakan berkorelasi positif terhadap kadar lemak dan protein tubuh ikan. Hal yang sama juga terjadi pada glikogen hati dan otot. Hasil penelitian juga menunjukkan bahwa peningkatan rasio energi-protein pakan berpengaruh nyata $(\mathrm{P}<0,05)$ dan berkorelasi positif terhadap kolesterol, trigliserida, HDL, dan albumin, tetapi tidak berpengaruh nyata terhadap LDL $(\mathrm{P}>0,05)$. Kesimpulan yang didapat adalah kinerja pertumbuhan optimal dihasilkan oleh kadar protein pakan 37,33\% dan rasio energi protein pakan $12,07 \mathrm{kcal} \mathrm{GE} / \mathrm{g}$.
\end{abstract}

Kata kunci: albumin, energi, ikan gabus, pertumbuhan, protein 


\section{INTRODUCTION}

Snakehead has become fish culture commodities with economic benefits. Snakehead fish is utilized in medical health to cure some diseases due to high albumin content, besides being a consumed fish (Mustafa et al., 2012). Medical health study proved that refined snakehead fish extract with $3 \times 10 \mathrm{~g}$ dose could replace $20 \%$ of human albumin (infuse solution) through the intravenous method with $1 \times 100 \mathrm{ml}$ doze, causing increased albumin level and decreased blood $\mathrm{pH}$ in hypoalbuminemia patient (Nugroho, 2016). Regardless of its benefits, snakehead fish culture is still lower than any other freshwater fish culture. This directly indicates that snakehead fish culture production needs to be improved.

Snakehead fish production data in Indonesia based on the Ministry of Marine and Fisheries (2015) only reached 6,490 tons. This number was very small compared to the production of freshwater fish such as tilapia fish which reached 912,613 tons in the same year. The low production of snakehead culture is due to the limited availability of snakehead fish seeds. Fish culturists mostly still rely on snakehead seeds from nature. In addition to seed availability, feed is also a major problem in snakehead fish culture. There has not been any special feed for snakehead fish as this fish is still given trash fish or commercial feed specialized for other fish species (Bijaksana, 2012; Yu et al., 2012).

Trash fish as feed material has some weaknesses, such as qualitative supply and quality followed with uncertain price, making it an unreliable source as major feed for rearing. The use of commercial feed specialized for other fish that exists in the market has a discrepancy on the nutrient composition needs for snakehead fish. This problem should be handled by applying special feed for snakehead fish. Special feed formed of pellet is formulated to fulfill the nutrient needs is an important factor for improving snakehead fish culture.

Snakehead fish that is given with different protein levels indicate different growth. Kusumaningrum et al. (2014) mentioned that the highest average growth rate of $(0.269 \mathrm{~g} /$ day $)$ was produced by $32 \%$ protein feed level, while the lowest $(0.128 \mathrm{~g} /$ day $)$ was produced by $26 \%$ protein feed level. Fish growth is influenced by its nutrient needs fulfillment, i.e. protein, lipid, carbohydrate, vitamins, and minerals. Protein has an important role in the growth and development process in fish body tissues (Lall \& Dumas,
2015). In addition, protein is also an efficient energy source for aquatic animals, particularly carnivorous fish (Zamora-Sillero et al., 2013). The number and quality of protein feed will affect growth. Fish protein requirements are influenced by various factors, such as fish size, environmental condition, feed quantity, digested feed energy content, and protein quality (Farhat \& Khan, 2011). Protein in the fish body will be used to fulfill vital tissue functions (daily maintenance) whether feed protein content is unavailable for fulfilling fish needs. Elsewhere, the protein will be excreted as metabolic waste, one of which is in the form of ammonia, whether protein feed exceeds the fish needs (Kpogue et al., 2013). Ammonia is excreted into the water that eventually may increase water ammonia level, endangering fish life in the environment.

Fish protein requirement regards with the total energy requirement (protein, carbohydrate, and lipid). Exceeded energy level in the feed will lead to fat degeneration in the tissue, reducing protein, vitamin, and mineral compositions, that are urgently needed to maintain metabolism and promote growth (Guo et al., 2012). Low energy level may cause the protein to become an energy source in the metabolism process. Therefore, proper protein-energy ratio for optimized growth rate and protein utilization should necessarily be given to the cultured fish (Kaushik \& Seiliez, 2010).

Snakehead fish study had been done by Samantary and Mohanty (1997), who mentioned that the best growth response in snakehead fish was obtained from $40 \%$ protein and $4,400 \mathrm{kcal} /$ $\mathrm{kg}$ energy level feed treatment with $3 \%$ of body weight per day. However, the feed conversion ratio was still high, which was 2.1. Aliyu-Paiko et al. (2010) mentioned that the best growth response of snakehead fish after commercial feed given was obtained from the combination of fish meal and casein as a supplement with 4,440 $\mathrm{kcal} / \mathrm{g}$ energy, $45 \%$ protein, and $6.5 \%$ lipid level. Based on the previous studies presented above, balanced protein level and protein-energy ratio in feed formulation was primarily required to fulfill the nutrient needs on each stadia fish cultured. Therefore, this study was conducted to determine the protein content and protein-energy ratio in commercial feed (artificial feed) formulation for optimum growth of snakehead fish. 
Table 1. Feed composition

\begin{tabular}{|c|c|c|c|c|c|c|}
\hline & \multicolumn{6}{|c|}{ Treatment } \\
\hline & $\mathrm{A}$ & $\mathrm{B}$ & $\mathrm{C}$ & $\mathrm{D}$ & $\mathrm{E}$ & $\mathrm{F}$ \\
\hline \multicolumn{7}{|l|}{$\overline{\text { Composition (g 100/g) }}$} \\
\hline Fish meal & 24.80 & 10.00 & 27.20 & 10.00 & 10.00 & 10.00 \\
\hline Soybean meal & 13.60 & 17.30 & 28.09 & 38.30 & 39.98 & 37.74 \\
\hline MBM & 10.00 & 10.00 & 6.30 & 10.00 & 14.87 & 10.30 \\
\hline PBM & - & 10.00 & - & 8.00 & 8.10 & 10.00 \\
\hline Blood meal & - & - & - & - & 2.00 & 5.00 \\
\hline Wheat pollard & 35.98 & 26.38 & 23.58 & - & $17, .58$ & - \\
\hline Wheat flour & - & 14.60 & 5.00 & 21.61 & - & 13.14 \\
\hline Cassava flour & 5.80 & 2.90 & - & - & - & - \\
\hline Cassava pulp & 5.00 & - & 5.00 & - & - & - \\
\hline Sardinella fish oil & 1.00 & 5.00 & 1.00 & 8.25 & 3.63 & 10.00 \\
\hline Salt & 0.50 & 0.50 & 0.50 & 0.50 & 0.50 & 0.50 \\
\hline PMC (binder) & 0.20 & 0.20 & 0.20 & 0.20 & 0.20 & 0.20 \\
\hline Mold inhibitor powder & 0.10 & 0.10 & 0.10 & 0.10 & 0.10 & 0.10 \\
\hline Phytase & 0.02 & 0.02 & 0.02 & 0.02 & 0.02 & 0.02 \\
\hline Premix & 3.00 & 3.00 & 3.00 & 3.00 & 3.00 & 3.00 \\
\hline \multicolumn{7}{|l|}{ Feed proximate } \\
\hline Moisture (\%) & 9.83 & 9.10 & 10.58 & 9.95 & 8.80 & 11.22 \\
\hline Protein $(\%)$ & 32.78 & 32.56 & 37.17 & 37.33 & 43.08 & 42.88 \\
\hline Lipid (\%) & 5.74 & 9.75 & 5.52 & 12.01 & 8.49 & 13.20 \\
\hline Crude fiber (\%) & 4.02 & 1.35 & 2.80 & 1.01 & 2.61 & 1.77 \\
\hline Ash $(\%)$ & 11.95 & 9.27 & 11.79 & 9.36 & 11.06 & 9.52 \\
\hline Energy (kcal/kg) & 3.873 & 4.336 & 3.956 & 4.505 & 4.317 & 4.564 \\
\hline Energi-protein ratio (kcal/g) & 11.82 & 13.32 & 10.64 & 12.07 & 10.02 & 10.66 \\
\hline \multicolumn{7}{|l|}{ Amino acid composition (\%) } \\
\hline Methionine & 0.80 & 0.80 & 0.89 & 0.80 & 0.83 & 1.06 \\
\hline Lysine & 1.91 & 1.98 & 2.24 & 2.26 & 2.38 & 2.85 \\
\hline Threonine & 1.22 & 1.21 & 1.44 & 1.43 & 1.65 & 1.67 \\
\hline Arginine & 2.09 & 2.18 & 2.43 & 2.56 & 2.91 & 2.77 \\
\hline Isoleucine & 1.22 & 1.24 & 1.50 & 1.54 & 1.66 & 1.60 \\
\hline Leucine & 2.19 & 2.22 & 2.61 & 2.67 & 3.10 & 3.25 \\
\hline Valine & 1.50 & 1.55 & 1.75 & 1.78 & 2.07 & 2.18 \\
\hline Histidine & 0.82 & 0.78 & 0.96 & 0.90 & 1.10 & 1.18 \\
\hline Phenylalanine & 1.30 & 1.35 & 1.57 & 1.63 & 1.87 & 1.94 \\
\hline Tryptophan & 0.35 & 0.34 & 0.42 & 0.40 & 0.46 & 0.47 \\
\hline Glycine & 2.31 & 2.50 & 2.33 & 2.56 & 3.07 & 2.87 \\
\hline Serine & 1.38 & 1.59 & 1.66 & 1.87 & 2.11 & 2.13 \\
\hline Proline & 1.83 & 2.15 & 2.02 & 2.41 & 2.66 & 2.58 \\
\hline Alanine & 1.88 & 1.86 & 2.05 & 2.00 & 2.41 & 2.41 \\
\hline Aspartic acid & 2.89 & 2.83 & 3.60 & 3.64 & 4.17 & 4.16 \\
\hline Glutamic acid & 4.86 & 5.14 & 5.93 & 6.34 & 6.72 & 6.58 \\
\hline Total & 28.55 & 29.72 & 33.40 & 34.79 & 39.17 & 39.70 \\
\hline
\end{tabular}

Note: Gross energy $1 \mathrm{~g}$ protein : $5.664 \mathrm{kcal}$ GE, $1 \mathrm{~g}$ lipid : 9,48 kcal GE, $1 \mathrm{~g}$ non protein extract material : 4.128 kcal GE (Halver et al., 2002)

\section{MATERIALS AND METHODS}

\section{Feed formulation}

Feed formulation was begun with the proximate analysis of feed materials used. Furthermore, based on a formula feed compiled, all macro materials (fish meal, poultry by-product meal (PBM), meat bone meal (MBM), soybean meal (SBM), wheat flour, etc.) were ground and sifted with mesh size 40 . The sifted results were measured based on the needs for formulation and mixed with mixer until homogeneous, then added with sardinella fish oil and micromaterials, such as premix and anti-mold. Feed dough was transferred into automatic pellet maker machine ( $2 \mathrm{~mm}$ size). Pellet made was dried in the oven. Dried pellet was cooled and packaged in a 
Table 2. feed intake (FI), protein retention (PR), lipid retention (LR), energy retention (ER), specific growth rate (SGR), feed efficiency (FE), survival rate (SR), and total of ammonia nitrogen (TAN) in snakehead fish on feed treatments with different protein and energy ratio

\begin{tabular}{|c|c|c|c|c|c|c|}
\hline \multirow[b]{2}{*}{ Parameter } & \multicolumn{6}{|c|}{ Treatment (protein content: energy-protein ratio) } \\
\hline & $\begin{array}{c}\mathrm{A} \\
(32.78: 11.82)\end{array}$ & $\begin{array}{c}\mathrm{B} \\
(32.56: 13.32)\end{array}$ & $\begin{array}{c}\mathrm{C} \\
(37.17: 10.64)\end{array}$ & $\begin{array}{c}\mathrm{D} \\
(37.33: 12.07)\end{array}$ & $\begin{array}{c}\mathrm{E} \\
(43.08: 10.02)\end{array}$ & $\begin{array}{c}\mathrm{F} \\
(42.88: 10.66)\end{array}$ \\
\hline FI $(g)$ & $21.24 \pm 3.41^{\mathrm{a}}$ & $21.22 \pm 3.3^{\mathrm{a}}$ & $21.94 \pm 2.08^{b}$ & $22.97 \pm 3.91^{\mathrm{d}}$ & $22.65 \pm 1.62^{\mathrm{cd}}$ & $22.39 \pm 1.53^{\mathrm{c}}$ \\
\hline $\mathrm{PR}(\%)$ & $27.83 \pm 0.99^{a}$ & $32.44 \pm 1.19^{\mathrm{b}}$ & $32.54 \pm 0.48^{b}$ & $39.58 \pm 3.35^{\mathrm{c}}$ & $31.31 \pm 0.54^{\mathrm{b}}$ & $30.91 \pm 0.78^{b}$ \\
\hline $\operatorname{LR}(\%)$ & $60.54 \pm 6.37^{\mathrm{ab}}$ & $72.10 \pm 7.34^{c}$ & $51.31 \pm 4.69^{\mathrm{a}}$ & $92.14 \pm 9.32^{\mathrm{d}}$ & $67.90 \pm 5.45^{\mathrm{bc}}$ & $74.20 \pm 7.40^{c}$ \\
\hline $\mathrm{ER}(\%)$ & $18.94 \pm 2.30^{\mathrm{a}}$ & $25.77 \pm 2.84^{\mathrm{b}}$ & $22, .35 \pm 1.65^{\mathrm{ab}}$ & $38.56 \pm 3.68^{\mathrm{d}}$ & $22.55 \pm 0.88^{\mathrm{ab}}$ & $31.59 \pm 2.93^{\mathrm{c}}$ \\
\hline $\begin{array}{c}\text { SGR } \\
\text { (\%/day) }\end{array}$ & $0.04^{\mathrm{a}}$ & $0.02^{\mathrm{bc}}$ & $0.01^{\mathrm{b}}$ & $0.02^{\mathrm{d}}$ & $0.01^{\mathrm{c}}$ & $1.87 \pm 0.01^{\mathrm{b}}$ \\
\hline $\mathrm{FE}(\%)$ & $52.60 \pm 1.34^{\mathrm{a}}$ & $60.71 \pm 0.09^{\mathrm{d}}$ & $57.37 \pm 0.95^{\mathrm{b}}$ & $68.87 \pm 1.11^{\mathrm{e}}$ & $58.70 \pm 0.05^{\mathrm{c}}$ & $56.38 \pm 0.20^{b}$ \\
\hline $\mathrm{SR}(\%)$ & 100 & 100 & 100 & 100 & 100 & 100 \\
\hline $\begin{array}{l}\text { TAN (mg/ } \\
\mathrm{kg} / \text { hour) }\end{array}$ & $15.62 \pm 1.71^{\mathrm{ab}}$ & $13.06 \pm 1.52^{\mathrm{a}}$ & $19.70 \pm 2.78^{\mathrm{bc}}$ & $12.28 \pm 1.66^{\mathrm{a}}$ & $22.23 \pm 4.18^{c}$ & $15.61 \pm 2.26^{\mathrm{ab}}$ \\
\hline
\end{tabular}

Different superscript letters on the same line indicate significantly different influence treatments $(\mathrm{P}<0.05)$; Numbers shown are average and standard deviation value.

sealed container. Feed was formulated using brill software program. The formulated feed consisted six treatments, treatment with the lowest range protein $32.5 \%$ was based on the protein level from pellet used for snakehead grow-out rearing by fish culturists, whereas treatment with the highest protein levels was based on the previous study by Samantary \& Mohanty (1997) and AliyuPaiko et al. (2010). Six treatments given were A $(32.78 \%$ protein, $11.82 \mathrm{kcal} / \mathrm{g}$ energy-protein ratio), B (32.56\% protein, $13.32 \mathrm{kcal} / \mathrm{g}$ energyprotein ratio), C (37.17\% protein, $10.64 \mathrm{kcal} / \mathrm{g}$ energy-protein ratio), D (37.33\% protein, 12.07 $\mathrm{kcal} / \mathrm{g}$ energy-protein ratio), E (43.08\% protein, $10.02 \mathrm{kcal} / \mathrm{g}$ energy-protein ratio), and $\mathrm{F}(42.88 \%$ protein, $10.66 \mathrm{kcal} / \mathrm{g}$ energy-protein ratio).

\section{Fish rearing}

This study used two months snakehead seeds caught from natural habitat. Snakehead seeds were obtained from a hatchery in Rengasdengklok, Karawang, West Java. Fish were acclimatized for a month and given a feed with low protein level and protein-energy ratio. Fish weighed $6.21 \pm$ $0.03 \mathrm{~g}$ were moved to fiber tank $(60 \mathrm{~cm} \times 60 \mathrm{~cm} \times$ $70 \mathrm{~cm}$ size) filled with approximately $150 \mathrm{~L}$ water with 10 fish per tank. Each fiber tank was given Eichhornia that served as shelters and closed using net $(0.5 \mathrm{~cm}$ mesh size) to avoid snakehead exiting the tank. Fish were adapted with formulated feed for seven days before the experiment began. Feed was given through determining feeding rate as much as $4 \%$ with four times frequency in a day, starting at $07.00,11.00,15.00,19.00$ during 60 days rearing.
Water quality was maintained by cleaning the tank from debris using the small hose (siphon) along with water exchange approximately $75 \%$. Syphonization and water exchange were done three times, namely in the morning, afternoon and evening. Water quality such as temperature, $\mathrm{pH}$, dissolved oxygen, and total ammonia nitrogen were measured periodically with the average value $28-31{ }^{\circ} \mathrm{C}, 7.8-8.1,3.5-4.5 \mathrm{mg} / \mathrm{L}$, and 0.12 $0.15 \mathrm{mg} / \mathrm{L}$ respectively. Fifteen seeds were taken for initial body sampling. Weight measurement sampling was done once every 2 weeks to adjust feeding quantities. Fish were anesthetized using MS222 with $150 \mathrm{mg} / \mathrm{L}$ during sampling.

Fish were not given any feed for 24 hours at the end of the study. Fish were counted and measured their body weight from each replication. Four of ten fish from each replication were taken randomly for proximate analysis. Blood samples from four fish were taken for blood biochemical analysis from each replication. Meat and liver of four fish were taken for glycogen analysis. Two fish remains from each replication were used for ammonia excretion analysis.

\section{Parameter}

Parameters obtained were proximate analysis, blood chemical, glycogen content, and total ammonia nitrogen level. Proximate analysis was performed on feed, initial fish body, and final fish body. The proximate analysis consisted of the measurement of moisture, protein, fat, ash, crude fiber, and glycogen level based on AOAC (2005). Blood biochemical containing plasma protein, albumin, glucose, cholesterol, LDL, HDL, and 
Table 3. Body proximate composition of snakehead fish on the initial and final experiment (\% wet weight)

\begin{tabular}{lccccccc}
\hline & \multicolumn{6}{c}{ Treatment (protein content: energy-protein ratio) } \\
\cline { 2 - 8 } Parameter & \multirow{2}{*}{ Initial } & $\mathrm{A}$ & $\mathrm{B}$ & $\mathrm{C}$ & $\mathrm{D}$ & $\mathrm{E}$ & $\mathrm{F}$ \\
& & $(32.78: 11.82)$ & $(32.56: 13.32)$ & $(37.17: 10.64)$ & $(37.33: 12.07)$ & $(43.08: 10.02)$ & $(42.88: 10.66)$ \\
\hline Moisture & $76.23 \pm 0.66$ & $73.32 \pm 0.64^{\mathrm{d}}$ & $71.32 \pm 0.28^{\mathrm{b}}$ & $72.56 \pm 0.31^{\mathrm{cd}}$ & $69.87 \pm 0.79^{\mathrm{a}}$ & $72.22 \pm 0.83^{\mathrm{bc}}$ & $71.40 \pm 0.39^{\mathrm{b}}$ \\
Protein & $15.25 \pm 0.17$ & $16.60 \pm 0.42^{\mathrm{a}}$ & $16.77 \pm 0.44^{\mathrm{a}}$ & $17.43 \pm 0.23^{\mathrm{ab}}$ & $17.82 \pm 1.07^{\mathrm{b}}$ & $16.77 \pm 0.20^{\mathrm{a}}$ & $17.07 \pm 0.32^{\mathrm{ab}}$ \\
Lipid & $4.07 \pm 0.05$ & $4.75 \pm 0.07^{\mathrm{a}}$ & $5.50 \pm 0.16^{\mathrm{b}}$ & $4.63 \pm 0.06^{\mathrm{a}}$ & $6.55 \pm 0.29^{\mathrm{d}}$ & $5.32 \pm 0.11^{\mathrm{b}}$ & $6.20 \pm 0.23^{\mathrm{c}}$ \\
NTE & $0.35 \pm 0.01$ & $0.74 \pm 0.03^{\mathrm{a}}$ & $0.76 \pm 0.05^{\mathrm{ab}}$ & $0.80 \pm 0.02^{\mathrm{bcd}}$ & $0.84 \pm 0.02^{\mathrm{d}}$ & $0.77 \pm 0.04^{\mathrm{abc}}$ & $0.82 \pm 0.03^{\mathrm{cd}}$ \\
Ash & $3.83 \pm 0.21$ & $4.43 \pm 0.45^{\mathrm{ab}}$ & $4.94 \pm 0.29^{\mathrm{b}}$ & $4.53 \pm 0.40^{\mathrm{ab}}$ & $4.56 \pm 0.41^{\mathrm{ab}}$ & $4.48 \pm 0.71^{\mathrm{ab}}$ & $4.16 \pm 0.14^{\mathrm{a}}$ \\
\hline
\end{tabular}

Note: Different superscript letters on the same line indicate significantly different influence treatments $(\mathrm{P}<0.05)$; Numbers shown are average and standard deviation value.

Table 4. Liver and muscle glycogen of snakehead fish (\% wet weight)

\begin{tabular}{ccccccc}
\hline \multirow{2}{*}{ Parameter } & \multicolumn{5}{c}{ Treatment (protein content: energy-protein ratio) } \\
\cline { 2 - 7 } & $\mathrm{A}$ & $\mathrm{B}$ & $\mathrm{C}$ & $\mathrm{D}$ & $\mathrm{E}$ & $\mathrm{F}$ \\
& $(32.78: 11.82)$ & $(32.56: 13.32)$ & $(37.17: 10.64)$ & $(37.33: 12.07)$ & $(43.08: 10.02)$ & $(42.88: 10.66)$ \\
\hline Liver glycogen (\%) & $0.20 \pm 0.01^{\mathrm{a}}$ & $2.15 \pm 0.21^{\mathrm{c}}$ & $0.30 \pm 0.03^{\mathrm{a}}$ & $5.21 \pm 0.51^{\mathrm{e}}$ & $3.29 \pm 0.19^{\mathrm{d}}$ & $0.76 \pm 0.05^{\mathrm{b}}$ \\
Muscle glycogen $(\%)$ & $0.15 \pm 0.01^{\mathrm{a}}$ & $0.20 \pm 0.02^{\mathrm{b}}$ & $0.16 \pm 0.01^{\mathrm{a}}$ & $0.31 \pm 0.03^{\mathrm{d}}$ & $0.24 \pm 0.01^{\mathrm{c}}$ & $0.19 \pm 0.02^{\mathrm{b}}$ \\
\hline
\end{tabular}

Note: Different superscript letters on the same line indicate significantly different influence treatments $(\mathrm{P}<0.05)$; Numbers shown are average and standard deviation value.

Table 5. Blood cholesterol, triglyceride, HDL, LDL, glucose, and albumin content of snakehead fish

\begin{tabular}{|c|c|c|c|c|c|c|}
\hline \multirow[b]{2}{*}{ Parameter } & \multicolumn{6}{|c|}{ Treatment (protein content: energy-protein ratio) } \\
\hline & $\begin{array}{c}\mathrm{A} \\
(32.78: 11.82)\end{array}$ & $\begin{array}{c}\mathrm{B} \\
(32.56: 13.32)\end{array}$ & $\begin{array}{c}\mathrm{C} \\
(37.17: 10.64)\end{array}$ & $\begin{array}{c}\mathrm{D} \\
(37.33: 12.07)\end{array}$ & $\begin{array}{c}\mathrm{E} \\
(43.08: 10.02)\end{array}$ & $\begin{array}{c}F \\
(42.88: 10.66)\end{array}$ \\
\hline $\begin{array}{c}\text { Cholesterol } \\
(\mathrm{mg} / \mathrm{dL})\end{array}$ & $144.75 \pm 15.44^{a}$ & $76.75 \pm 3.86^{b}$ & $154.50 \pm 7.23^{\mathrm{a}}$ & $183 \pm 7.96^{\mathrm{b}}$ & $174 \pm 9.42^{b}$ & $187.50 \pm 7.55^{\mathrm{b}}$ \\
\hline $\begin{array}{c}\text { HDL } \\
(\mathrm{mg} / \mathrm{dL})\end{array}$ & $31.00 \pm 5.16^{\mathrm{a}}$ & $54.00 \pm 4.39^{\mathrm{b}}$ & $36.00 \pm 4.39^{\mathrm{a}}$ & $57.00 \pm 2.58^{\mathrm{b}}$ & $55.00 \pm 2.45^{\mathrm{b}}$ & $59.00 \pm 5.35^{\mathrm{b}}$ \\
\hline $\begin{array}{c}\text { LDL } \\
(\mathrm{mg} / \mathrm{dL})\end{array}$ & $88.55 \pm 6.94^{a}$ & $90.45 \pm 1.70^{\mathrm{a}}$ & $90.60 \pm 0.71^{\mathrm{a}}$ & $92.80 \pm 3.46^{\mathrm{a}}$ & $90.80 \pm 5.37^{\mathrm{a}}$ & $94.30 \pm 1.62^{\mathrm{a}}$ \\
\hline $\begin{array}{c}\text { Triglyseride }(\mathrm{mg} / \\
\mathrm{dL})\end{array}$ & $126.00 \pm 18.06^{\mathrm{a}}$ & $161.50 \pm 5.92^{\mathrm{b}}$ & $139.50 \pm 11.45^{\mathrm{a}}$ & $166.00 \pm 11.05^{b}$ & $141.00 \pm 9.42^{\mathrm{a}}$ & $171.00 \pm 14.51^{b}$ \\
\hline Glucose $(\mathrm{mg} / \mathrm{dL})$ & $104 \pm 11.89^{\mathrm{bc}}$ & $112.5 \pm 18.81^{\mathrm{bc}}$ & $107 \pm 11.37^{\mathrm{bc}}$ & $115 \pm 6.98^{c}$ & $93.33 \pm 13.47^{\mathrm{ab}}$ & $84 \pm 3.65^{\mathrm{a}}$ \\
\hline $\begin{array}{l}\text { Albumin } \\
\text { (g/dL) }\end{array}$ & $1.55 \pm 0.13^{\mathrm{a}}$ & $1.85 \pm 0.13^{\mathrm{b}}$ & $1.6 \pm 0.08^{\mathrm{a}}$ & $2.2 \pm 0.18^{c}$ & $1.6 \pm 0.08^{\mathrm{a}}$ & $1.75 \pm 0.13^{\mathrm{ab}}$ \\
\hline
\end{tabular}

Different superscript letters on the same line indicate significantly different influence treatments $(\mathrm{P}<0.05)$; Numbers shown are average and standard deviation value.

triglycerides was analyzed using by of enzymatic colorimetric method with a test kit, while ammonia excretion content was analyzed using APHA 2005 method.

\section{Data analysis}

This study applied complete randomized design with six treatments and four replications. Data results were processed using ANOVA analysis with a 95\% degree of confident level by SPSS 16.0 software analysis. Duncan's multiple range test was performed whether the analyzed data showed any significant difference among treatments.

\section{RESULTS AND DISCUSSION}

\section{Results}

Growth performance parameters, such as feed intake (FI), protein retention (PR), lipid retention (LR), energy retention (ER), specific growth rate (SGR), feed efficiency (FE) (Halver et al., 2002), and ammonia excretion of snakehead fish during 60 days rearing are presented in Table 2.

Table 2 shows that different protein and proteinenergy ratio significantly influenced FI. FI between $\mathrm{A}$ and $\mathrm{B}$ treatment did not differ significantly $(\mathrm{P}>0.05)$, while $\mathrm{C}$ and $\mathrm{D}$ treatment differed significantly $(\mathrm{P}<0.05)$, besides significantly different from A and B treatment. However, FI on $\mathrm{E}$ and $\mathrm{F}$ treatment decreased when compared 
to D treatment. FI on D treatment was $22.97 \pm$ $3.91 \mathrm{~g}$. Feed treatments with different protein and energy-protein ratio influenced significantly $(\mathrm{P}$ $<0.05$ ) on PR, LR, and ER. Increased energyprotein ratio on $\mathrm{B}$ and $\mathrm{D}$ treatment induced the percentage of PR, LR, and ER. However, the PR level on $\mathrm{E}$ and $\mathrm{F}$ treatment decreased significantly compared to fish fed with $\mathrm{D}$ treatment feed $(\mathrm{P}<$ $0.05)$. A, B, C, and D treatment showed increased SGR along with the increased level of energyprotein ratio, yet it showed contradiction result on $\mathrm{E}$ and $\mathrm{F}$ treatment, whereas high energyprotein ratio inversely influenced SGR. The same condition also happened on feed efficiency value. The lowest feed efficiency was demonstrated by the fish fed with low protein and energy-protein ratio (A). The survival rate of the fish on this study was $100 \%$ in each treatment. Ammonia excretion rates tended to increase in line with increased feed protein level and decreased on higher energy-protein ratio. The highest level of TAN excretion $(22.23 \pm 4.18 \mathrm{mg} / \mathrm{kg} /$ hour $)$ was found on $\mathrm{E}$ treatment, while the lowest was obtained on D treatment.

Proximate composition of snakehead fish body is presented on Table 3. Different protein and energy-protein ratio level influenced moisture, protein, lipid, non-nitrogen material extract(NTE), and ash content on snakehead fish body $(\mathrm{P}<0.05)$. Feed influence on fish proximate composition in each treatment showed that increased protein, lipid, ash, and NTE content on fish at the end of the study was in line with increased feed protein and energy-protein ratio. However, high feed protein and energy-protein ratio level decreased body moisture content significantly.

Protein content and energy-protein ratio in the feed also significantly influenced liver and muscle glycogen $(\mathrm{P}<0.05)$. Liver and muscle glycogen can be seen in Table 4. Treatment A, B, C, and $\mathrm{D}$ increased liver and muscle glycogen content along with an increased level of protein-energy ratio. However, increased protein energy ratio decreased liver and muscle glycogen content on treatment $\mathrm{E}$ and $\mathrm{F}$.

Blood biochemical analysis result containing cholesterol, triglyceride, low- density lipoprotein (LDL), high-density liporotein (HDL), glucose, and albumin content are presented in Table 5. Blood profiles analysis result showed that different protein content and protein energy ratio influenced significantly on cholesterol, triglyceride, HDL, glucose, and albumin content $(\mathrm{P}<0.05)$. Meanwhile, LDL content was not significantly different $(\mathrm{P}>0.05)$ among treatments.

\section{Discussion}

Feed treatment with different protein and energy-protein ratio affected the growth performance. The growth performance measured parameters on snakehead fish were feed intake $(\mathrm{FI})$, protein retention (PR), lipid retention (LR), energy retention (ER), specific growth rate (SGR), feed efficiency (FE), and ammonia excretion. FI on A and B treatment had the lowest value among other treatments. This was alleged because of the low level of alanine and glutamic acid in the feed as the free amino acid, which acts as an attractant, affecting the decreased level of feed palatability. This was in accordance with Tantikitti (2014), who mentioned that free amino acid, especially taurine, hydroxyproline, glycine, arginine, glutamic acid, and alanine influenced increased palatability on shrimp.

$\mathrm{C}, \mathrm{D}$, and $\mathrm{E}$ treatment showed improved FI value along with increased protein and energy-protein level feed. This was in line with African catfish (Farhat \& Khan, 2011) and rockfish (Sebastes schlegeli) (Cho et al., 2015). However, feed with $42.5 \%$ protein and $10.66 \mathrm{GE}$ $\mathrm{kcal} / \mathrm{g}$ energy-protein ratio ( $\mathrm{F}$ treatment) caused increased feed lipid content, thus lowering the feed palatability. This was in accordance with $\mathrm{Ng}$ et al. (2008), who claimed that excess fat in feed was not recommended as it lowered the amount of feed consumption. This was also reported similarly by Cheng et al. (2013) on marble eel (Anguilla marmorata) and Okorie et al. (2007) on Japanese eel (A. japonica).

Based on the study result, increased energyprotein ratio on the same feed protein level could increase the percentage value of PR, LR, and ER (B and D treatment). This shows that fish fed on B and D could depress protein specific dynamic action (SDA) and catabolism energy, thus efficiently utilized protein as growing factor (protein sparing effect) with decreased total heat increment (Ding et al., 2010; Hasan \& Khan, 2013; Suprayudi et al., 2014). This is supported by Kaushik and Seiliez (2010), who reported that the utilization of protein and optimized fish growth could be delivered with certain energyprotein ratio. Furthermore, Khan \& Abidi (2012) stated that the utilization of proteins depended on the nonprotein energy source in the feed which affected growth, feed conversion, feed efficiency, nutrient retention, and body composition.

Protein requirement and fish growth have a 
proportional relationship. This caused protein and protein-energy ratio in feed treatment should be in line with fish requirements, making the feed given become efficient and produce optimum growth (Setiawati et al., 2008). Accurate energyprotein ratio on $\mathrm{D}$ treatment showed high protein utilization stored into the fish body, resulting in lowered ammonia excretion, i.e. $12.28 \pm 1.66 \mathrm{mg} /$ $\mathrm{kg} /$ hour. A similar condition was also reported by Suprayudi et al. (2014) on the bluefin trevally (Caranx melampygus) and Guo et al. (2012) in hybrid sturgeon.

Feed PR value containing $42.5 \%$ protein decreased drastically compared to fish fed on $\mathrm{D}$ treatment $(\mathrm{P}<0.05)$. This condition figured a theory that excess protein content would reconstruct most of it into energy. The number of oxidative deaminated protein led to increased ammonia excretion. High protein given (E and $\mathrm{F}$ treatment) would induce increased protein catabolism into energy, which reduced growth and feed efficiency (Kpogue et al., 2013). A similar condition was also reported by Kim et al. (2016) on parrot fish (Oplegnathus fasciatus) and Ozo'rio et al. (2009) on seabream fish (Diplodus vulgaris). Survival rate during this study was observed at $100 \%$ in all treatments. This indicates that the feed quality given to the entire treatments was able to fulfill snakehead fish nutrient requirements and proved that the feeding rate and aquatic environment were suitable to meet basic terms of fish to live and grow (Nawir et al., 2015).

Body protein content increased along with the increased level of feed protein and energy-protein ratio, based on Kim et al. (2016) on juvenile parrot fish (O. fasciatus). Body protein content was affected by protein feed intake and piled protein in the body, which was positively correlated with feed protein content. This result was the same with Rema et al. (2008) on Senegalese sole, Kim and Lee (2009) on tiger puffer (Takifugu rubripes), and Zhang et al. (2010) on black seabream (Sparus macrocephalus). The analysis result of proximate body composition also showed increased body lipid content along with increased feed lipid content. High body lipid content in fish was caused by increased lipid consumption from high feed lipid content. Consumed feed lipid without utilized as an energy source would be deposited as body lipid. Rahimnejad et al. (2015) argued that high lipid content in feed will be deposited as lipid whether unutilized as an energy source.

Some study suggested that increased feed lipid content influenced significantly on enhanced fish body lipid content as reported by Tian et al.
(2012) on grass carp (Ctenopharyngodon idella) and Adamidou et al. (2011) on sharp snout seabream (Diplodus puntazzo). The current study was oppositely different from other studies as moisture content of the fish body was contradictive with fish body lipid content. This study result was reported by Mohseni et al. (2011) on Persian sturgeon (Acipenser persicus). Increased protein and energy-protein level significantly lowered the feed moisture content in fish body. This suggests that increased energy-protein level in feed affected fish flesh texture. Moisture level on fish body reflects as the indicator of assessing relative energy and lipid content, as well as protein content. Low moisture content in the fish body tends to cause high protein and lipid level (Dempson et al., 2004). High moisture level affected the fish flesh texture produced, becoming mushy (Suryaningrum et al., 2010).

Liver and muscle glycogen increased along with increased feed energy level. This shows that the energy requirement was fulfilled on high feed energy content, elevating the synthesis of glycogen from glucose. Based on the study data on liver and muscle glycogen value, liver glycogen were greater than muscle. Increased liver and muscle glycogen in fish fed with high feed energy was the same with Enes et al. (2009) and Wu et al. (2015) on hybrid striped bass fish.

Lipid in fish is transported as lipoproteins, involving LDL and HDL. The main function of HDL is transporting cholesterol from body tissues to the liver, while LDL was transporting cholesterol from the liver to the body tissues (Luo et al., 2014). This study result suggests that cholesterol, HDL, and LDL were increased along with increased protein and energy-protein ratio level. This was in accordance with Jiang et al. (2015) who mentioned that cholesterol, HDL, and LDL was influenced by feed protein and lipid level. In this study, increased triglyceride aligned with increased lipid level shows that lipid transportation was more active on feed containing high lipid content. This was in line with Jiang et al. (2015) on hybrid grouper and Wang et al. (2017) on juvenile red-spotted grouper.

Feed protein and energy significantly affected blood glucose. This was in accordance with Okorie et al. (2007) on Japanese eel, A. japonica. Glucose played an important role as an energy source. Excess glucose is stored as when the amount of glucose is more than required. However, the body ability to store glycogen was limited, thus modifying excess glycogen into triglycerides (Kersten, 2001). This study result 
demonstrated the glucose level of snakehead fish was ranging from $84-115 \mathrm{mg} / \mathrm{dL}$. Blood glucose levels in all treatments were generally still in the normal range, based on the normal range of blood glucose approach on Tilapia fish, which is 32-137 mg/dL (Mauel et al., 2007).

The result showed that albumin was affected significantly by feed protein and energy-protein ratio level $(\mathrm{P}<0.05)$. Increased level of protein and energy-protein ratio induced albumin level. This was in accordance with Balmer (2001) who stated that albumin is an amino acid deposit and fish adaptation against high feed protein content would affect the high synthesis and catabolic of albumin. The feed with $37.33 \%$ protein and 12.07 $\mathrm{kcal} \mathrm{GE} / \mathrm{g}$ energy-protein ratio produced the best growth performance in snakehead fish.

\section{CONCLUSION}

Different protein content and energy-protein ratio gave a significant influence on growth performance (feed intake, specific growth rate, feed efficiency, protein retention, lipid retention, and energy retention) $(\mathrm{P}<0.05)$. The protein content of $37.33 \%$ and energy-protein ratio of $12.07 \mathrm{kcal} \mathrm{GE} / \mathrm{g}$ gave optimum growth performance for snakehead fish.

\section{REFERENCES}

Adamidou S, Rigos G, Mente E, Nengas I, Fountoulaki E. 2011. The effects of dietary lipid and fibre levels on digestibility of diet and on the growth performance of sharpsnout seabream Diplodus puntazzo. Mediterranean Marine Science 12: 401-412.

Aliyu-Paiko M, Hashim R, Chong AS, Yogarajag L, El-Sayed AM. 2010. Influence of different sources and level of dietary protein and lipid on the growth, feed efficiency, muscle composition and fatty acid profile of snakehead Channa striatus (Bloch, 1793) fingerling. Aquaculture Research 41: 1365-1376.

[APHA] American Public Health Association. 2005. 4500- $\mathrm{NH}_{3}$ Nitrogen (Ammonia). In: Eaton AD, Clesceri LS, Rice EW, Greenberg AE (eds). Standard Methods for The Examination of The Water and Wastewater, 21st ed. Washington DC, USA: APHA, American Water Works Association (AWWA) and Water Environment Federation (WEF). pp. 4-117

[AOAC] Association of Official Analytical
Chemists. 2005. Official Method of Analysis of The Association of Official Analytical Chemist. Arlington, Virginia: Association of Official Analytical Chemists. Inc.

Balmer PE. 2001. Chauses and mechanisms of hypoalbuminaemia. Clinical Nutrition 20: 271-273.

Bijaksana U. 2012. Snakehead domestication, Channa striata (Blkr), swamp water optimization efforts in South Kalimantan Province. Jurnal Lahan Suboptimal 1: 92-101.

Cheng W, Lai CS, Lin YH. 2013. Quantifying the dietary protein and lipid requirements of marble eel Anguilla marmorata with different body weight. Fisheries Society 40: 135-142.

Cho SH, Kim HS, Myung SH, Jung WG, Choi J, Lee SM. 2015. Optimum dietary protein and lipid levels for juvenile rockfish Sebastes schlegeli (Hilgendorf 1880). Aquaculture Research 46: 2954-2961.

Dempson IB, Schwarz CJ, Shears M, Furey G. 2004. Comparative proximate body composition of Atlantic Salmon with emphasis on parr from fluvial and lacustrin habitats. Journal of Fish Biology 64: 1257-1271.

Ding LY, Zhang LM, Wang JY, Ma JJ, Meng XJ, Duan PC, Sun YZ. 2010. Effect of dietary lipid level on the growth performance, feed utilization, body composition, and blood chemistry of juvenile starry flounder, Platichthys stellatus. Aquaculture Research 41: 1470-1478.

Enes P, Panserat S, Kaushik S, Oliva-Teles A. 2009. Nutritional regulation of hepatic glucose metabolism in fish. Fish Physiology and Biochemistry 35: 519-539.

Farhat KMA, Khan MA. 2011. Growth, feed conversion, and nutrient retention efficiency of African catfish, Clarias gariepinus (Burchell) fingerling fed diets with varying levels of protein. Journal of Applied Aquaculture 23: 304-316.

Guo Z, Zhu X, Liu J, Yang Y, Lan Z, Xie S. 2012. Effects of dietary protein level on growth performance, nitrogen, and energy budget of juvenile hybrid sturgeon Acipenser baerii $\times A$. gueldenstaedtii. Aquaculture 338: 89-95.

Halver JE, Hardy RW. 2002. Fish Nutrition. California: Academic Press.

Hasan AJZ, Khan U. 2013. Protein sparring effect and the efficiency of different compositions of carbohydrates, lipids, and protein on the growth of rohu, Labeo rohita fingerlings. World Journal of Marine Science 5: 244-250. 
Jiang YD, Wang JT, Han T, Li XY, Hu SX. 2015. Effect of dietary lipid level on growth performance, feed utilization, and body composition by juvenile red spotted grouper, Epinephelus akaara. Aquaculture International 23: 99-110.

Jiang S, Wu X, Li W, Wu M, Luo Y, Lu S, Lin H. 2015. Effects of dietary protein and lipid levels on growth, feed utilization, body, and plasma biochemical compositions of hybrid grouper Epinephelus lanceolatus $\times$ Epinephelus fuscoguttatus juveniles. Aquaculture 446: 148-155.

Kaushik SJ, Seiliez I. 2010. Protein and amino acid nutrition and metabolism in fish: current knowledge and future needs. Aquaculture Research 41: 322-332.

[KKP] Kementerian Kelautan dan Perikanan. 2015. Statistik Perikanan Budidaya Indonesia. Jakarta: Direktorat Jenderal Perikanan Budidaya.

Kersten S. 2001. Mechanisms of nutritional and hormonal regulation of lipogenesis. EMBO Reports 21: 282-286.

Khan MA, Abidi SF. 2012. Effect of varying protein to energy ratio on growth, nutrient retention, somatic indices, and digestive enzymes activities of singhi, Heteropneustes fossilis (Bloch). Journal of World Aquaculture Society 43: 490-501.

Kim SS, Lee KJ. 2009. Dietary protein requirement of juvenile tiger puffer, Takifugu rubripes. Aquaculture 287: 219- 222.

Kim KW, Kim KD, Han HS, Moniruzzaman M, Yun H, Lee S, Bai SC. 2016. Optimum dietary protein level and protein-to-energy ratio for growth of juvenile parrot fish, Oplegnathus fasciatus. Journal of World Aquaculture Society 48: 467-477.

Kpogue D, Gangbazo H, Fiogbe E. 2013. A preliminary study on the dietary protein requirement of Parachanna obscura (Gunther, 1861) larvae. Journal of Fisheries and Aquatic Sciences 13: 111-117.

Kusumaningrum GA, Alamsjah MA dan Masithah ED. 2014. Albumin level test and snakehead fish, Channa striata growth with different commercial feed protein level. Jurnal Ilmiah Perikanan dan Kelautan 6: 25-19

Lall SP, Dumas A. 2015. Nutritional requirements of cultured fish: formulating nutritionally adequate feeds. Feed and Feeding Practices in Aquaculture. Woodhead Publishing Series in Food Science, Technology and Nutrition
53-109.

Luo L, Xue M, Vachot C, Geurden I, Kaushik S. 2014. Dietary medium chain fatty acids from coconut oil have little effects on postprandial plasma metabolite profiles in rainbow trout, Oncorhynchus mykiss. Aquaculture 420: 2431.

Mauel MJ, Miller DL, Merril AL. 2007. Hematologic and plasma biochemical values of healthy hybrid tilapia Oreochromis aureus $\times$ Oreochromis nilotica maintained in a recirculating system. The Journal of Zoo and Wildlife Medicine 38: 420-424.

Mohseni M, Pourkazemi M, Hosseni MR, Hassani MHS, Bai SC. 2011. Effects of the dietary protein levels and the protein to energy ratio in sub-yearling Persian sturgeon, Acipenser persicus (Borodin). Aquaculture Research 44: 378-387.

Mustafa AM, Aris W, Yohanes K. 2012. Albumin and zinc content of snakehead fish, Channa striata extract and its role in health. IEESE International Journal of Science Technology and Engineering (IJSTE) 1: 1-8.

Nawir F, Utomo NBP, Budiardi T. 2015. The growth of eel fed with different protein level and protein-energy ratio. Jurnal Akuakultur Indonesia 14: 128-134.

Ng WK, Abdullah N, De Silva SS. 2008. The dietary protein requirement of the Malaysian mahseer, Tor tambroides (Bleeker), and the lack of protein-sparing action by dietary lipid. Aquaculture 284: 201-206.

Nugroho AY. 2016. The comparison effectiveness of pure snakehead fish extract therapy compare with human albumin $20 \%$ on blood albumin level and blood $\mathrm{pH}$ in the hypoalbuminemic patient. [Thesis]. Surakarta: Program Pascasarjana Universitas Sebelas Maret.

Okorie EO, Kim YC, Lee S, Bae JY, Yoo JH, Han K, Bai SC, Park GJ, Choi SM. 2007. Reevaluation of the dietary protein requirements and optimum dietary protein to energy ratios in Japanese eel, Anguilla japonica. Journal of World Aquaculture Society 38: 418-426.

Ozo'rio ROA, Valente LMP, Correia S, PousaoFerreira P, Damasceno-Oliveira A, Ecorcio C, Oliva-Teles A. 2009. Protein requirement for maintenance and maximum growth of twobanded seabream, Diplodus vulgaris juveniles. Aquaculture Nutrition 15: 85-93.

Rahimnejad S, Ban IC, Park JY, Sade A, Choi J, Lee SM. 2015. Effects of dietary protein 
and lipid levels on growth performance, feed utilization and body composition of juvenile hybrid grouper, Ephinephelus fuscoguttatus $\times$ E. lanceolatus. Aquaculture 446: 283-289.

Rema P, Conceicao LEC, Evers F, Castro-Cunha M, Dinis MT, Dias J. 2008. Optimal dietary protein levels in juvenile Senegalese sole, Solea senegalensis. Aquaculture Nutrition 14: 263-269.

Samantary K, Mohanty SS. 1997. Interactions of dietary levels of protein and energy on fingerling snakehead, Channa striata. Aquaculture 156: 241-253.

Setiawati M, Sutajaya R, Suprayudi MA. 2008. Effect of different protein and protein-energy ratio in diet on growth of common carp, Cyprinus carpio. Jurnal Akuakultur Indonesia 7: 171-178.

Suprayudi MA, Ihu MZ, Utomo NBP, Ekasari J. 2014. Protein and energy: protein ratio in diets for juvenile bluefin trevally, Caranx melampygus. Journal of Applied Aquaculture 26: 187-196.

Suryaningrum DT, Muljanah I, Tahapari E. 2010. Profil sensori dan nilai gizi beberapa jenis ikan patin dan hibrid nasutus. Jurnal Pascapanen dan bioteknologi kelautan dan perikanan 5: 153-164.

Tantikitti C. 2014. Feed palatability and the alternative protein sources in shrimp feed. Songklanakarin Journal of Science and Technology 36: 51-55.

Tian LX, Liu YJ, Yang HJ, Liang GY, Niu J. 2012. Effect of different dietary wheat starch level on growth feed efficiency and digestability in grass carp, Ctenopharyngodon idella. Aquaculture International 20: 283-293. Wang JT, Han T, Li XY, Yang YX, Yang M, Hu SX, Jiang YD, Harpaz S. 2017. Effects of dietary protein and lipid levels with different protein to energy ratios on growth performance, feed utilization and body composition of juvenile red- spotted grouper, Epinephelus akaara. Aquaculture Nutrition 23: 994-1002.

Wu XY, Castillo S, Rosales M, Burn A, Mandoza M, Gatlin III DM. 2015. Relative use of dietary carbohydrate, non-essential amino acids, and lipids for energy by hybrid striped bass, Morone chrysops $\times$ M. saxatilis. Aquaculture 435: 116-119.

Yu HR, Zhang Q, Cao H, Wang XZ, Huang QQ, Zhang BR, Fan JJ, Liu SW, Li WZ, Cui Y. 2012 Apparent digestibility coefficients of selected feed ingredients for juvenile snakehead, Ophiocephalus argus. Aquaculture Nutrition 19: 139-147.

Zamora-Sillero J, Ramos LRV, Romanol LA, Monserrat JM, Tesser MB. 2013. Effect of dietary dextrin levels on the growth performance, blood chemistry, body composition, hepatic triglicerides, and glycogen of lebranche mullet juveniles, Mugil liza (Valenciennes 1836, Mugilidae). Journal of Applied Ichthyology 29: 1342-1347.

Zhang J, Zhou F, Wang LL, Shao Q, Xu Z, Xu J. 2010. Dietary protein requirement of juvenile black seabream, Sparus macrocephalus. Journal of World Aquaculture Society 41: 151-164. 